Documentation et bibliothèques

DOCUMENTATION BIBLIOTHEQUES

\title{
Le contrôle d'autorité : implications sur les réseaux de
} catalogage Authority control: its impact on cataloging networks
El control de autoridad: implicaciones sobre las redes de
catalogación

Alain Rochefort

Volume 31, numéro 4, octobre-décembre 1985

URI : https://id.erudit.org/iderudit/1052730ar

DOI : https://doi.org/10.7202/1052730ar

Aller au sommaire du numéro

Éditeur(s)

Association pour l'avancement des sciences et des techniques de la documentation (ASTED)

ISSN

0315-2340 (imprimé)

2291-8949 (numérique)

Découvrir la revue

Citer cet article

Rochefort, A. (1985). Le contrôle d'autorité : implications sur les réseaux de catalogage. Documentation et bibliothèques, 31(4), 151-157.

https://doi.org/10.7202/1052730ar

\section{Résumé de l'article}

L'auteur discute des implications du contrôle d'autorité sur les réseaux de catalogage. Dans un premier temps, il définit cette pratique du traitement descriptif et présente les raisons pour lesquelles elle est effectuée. Les conditions que doivent remplir les bibliothèques pour participer à un réseau de catalogage sont ensuite examinées et les coûts et les bénéfices d'une telle participation analysés.
Tous droits réservés $@$ Association pour l'avancement des sciences et des techniques de la documentation (ASTED), 1985
Ce document est protégé par la loi sur le droit d'auteur. L'utilisation des services d'Érudit (y compris la reproduction) est assujettie à sa politique d'utilisation que vous pouvez consulter en ligne.

https://apropos.erudit.org/fr/usagers/politique-dutilisation/ 
Le contrôle d'autorité: implications sur les réseaux de catalogage

\author{
Alain Rochefort* \\ Université de Montréal
}

L'auteur discute des implications du contrôle d'autorité sur les réseaux de catalogage. Dans un premier temps, il définit cette pratique du traitement descriptif et présente les raisons pour lesquelles elle est effectuée. Les conditions que doivent remplir les bibliothèques pour participer à un réseau de catalogage sont ensuite examinées et les coûts et les bénéfices d'une telle participation analysés.

\section{Authority control: its impact on cataloging networks}

The author discusses the implications of authority control on cataloging networks. Firstly, he defines this method in descriptive cataloging, and lists the reasons for such a practice. The conditions that must be met by a library to participate in a cataloging network are then examined, and the costs and profits of this participation are analyzed.

\section{El control de autoridad: implicaciones sobre las redes de catalogación}

El autor discute las implicaciones del control de autoridad sobre las redes de catalogación. En primer lugar, define esta práctica del tratamiento descriptivo y presenta el porqué de su realización. Examina las condiciones que deben cumplir las bibliotecas para participar en una red de catalogación y analiza a continuación los gastos y los beneficios de esta participación.
Le contrôle d'autorité existe depuis longtemps au niveau du traitement descriptif en bibliothéconomie. En fait, même si ce concept n'est entré que récemment dans l'usage courant, nous savons que Cutter reconnaissait déjà, en 1876, l'importance et la nécessité du contrôle d'autorité dans la préparation et le maintien des fichiers bibliographiques, pour assurer notamment l'efficacité en tant qu'instruments de repérage dans les bibliothèques. Bien qu'il ait été négligé par la suite, et même oublié, celui-ci est réapparu en force au cours des dernières années avec l'automatisation croissante des fichiers bibliographiques, l'adoption des RCAA2, et la création des réseaux de catalogage. Ainsi, le contrôle d'autorité est actuellement l'objet d'un renouveau d'intérêt dans les domaines de la bibliothéconomie et des sciences de l'information. Mais avant d'examiner de plus près cette activité propre au catalogage, il est essentiel de bien définir ce qu'est le contrôle d'autorité et de voir ce qu'il comporte dans la pratique.

\section{Le contrôle d'autorité}

Au cours des dernières années, plusieurs définitions du contrôle d'autorité ont été avancées par des spécialistes dans le domaine comme Schmierer ${ }^{1}$, Hagler et Simmons ${ }^{2}$, Avram $^{3}$, Martin $^{4}$, Elias $^{5}$, Bulaong ${ }^{6}$ et d'autres encore. En reproduisant quelques-unes de celles-ci dans un récent état de la question, $\mathrm{Clack}^{7}$ constate qu'elles présentent toutes des caractéristiques communes et elle en déduit que ces experts s'entendent assez bien sur le sens qu'il faut donner à ce concept. Dans un effort de synthèse, elle présente ainsi sa propre définition du contrôle d'autorité:

Summarily, authority control is the process of insuring that every entry - name, uniform title, series, or subject - that is selected as an access point for the public catalog is unique and does not conflict, by being identical, with any other entry that is already in the catalog or that may be included at a later date. A network of «see» and

\footnotetext{
- L'auteur est étudiant à l'École de bibliothéconomie et des sciences de linformation de l'Université de Montréal.

1. Doris Hargrett Clack, «Authority control : Issues and answers» Technical Services Quarterly, vol. 3, no. 1-2 (1985-1986), 128

2. Ibid.

3. Ibid.
}
4. Ibid.
5. Ibid.
6. Grace Bulaong, «Authorities and Standards in a Changing World, Part 2», International Cataloguing, vol. 11, no. 4 (1982), 41
7. Doris Hargrett Clack, «Authority Control...», 128 
"see also" references is the frame that ties it all together ${ }^{8}$.

Le contrôle d'autorité est un processus technique comprenant des opérations ou activités de recherche ("authority work») effectuées par des catalogueurs ou bibliothécaires professionnels dans le fichier ou le catalogue d'une bibliothèque en vue de l'organiser et de lui procurer une structure dite "Syndetic» 9 , ou conjonctive. Ce processus consiste notamment à choisir, à établir et à utiliser une seule forme normalisée pour chaque vedette principale ou secondaire (nom de personne ou de collectivité, titre uniforme, titre de collection, vedette-matière) portée au catalogue d'une bibliothèque et servant de point d'accès à une ou des notices bibliographiques ou à l'aide d'ouvrages de référence (encyclopédies, atlas, dictionnaires, répertoires spécialisés, etc.); ou encore, elles peuvent être adoptées d'une bibliothèque, source d'autorité, comme la Library of Congress (LC Name Authority List, par exemple) ${ }^{10}$.

Par ailleurs, le contrôle d'autorité doit aussi vérifier et s'assurer que chaque forme standardisée de vedette soit unique, ait un sens fixe, bien défini, et qu'elle ne soit pas identique aux vedettes (variantes, synonymes, ou autres) déjà consignées, ou qui pourraient l'être à une date ultérieure. Aussi, il faut créer un réseau de renvois réciproques "voir aussi», et assurer ainsi des liens entre les différentes formes que prennent les vedettes portées au catalogue ${ }^{11}$.

Finalement, on doit enregistrer les sources consultées (ouvrages de référence, LC Name A uthority List, etc.) qui ont permis d'établir chaque forme standardisée de vedette, les formes variantes (non-adoptées) de cette vedette, ainsi que l'information sur les décisions qui ont été prises à cet effet (justifications du choix des formes de vedettes).

Les bibliothécaires professionnels qui exécutent les tâches du contrôle d'autorité ("authority work») doivent voir ensuite à ce que chaque forme établie de vedette, les formes variantes de cellesci ainsi que l'information s'y rapportant (" authority data») soient rassemblées et consignées ensemble dans une notice d'autorité ("authority record»):

These data are maintained together so that when an established authorized form is used as an access point, its use may be understood in a context, and so that when any additions or changes are made to the authority data, they may be made in the context of information previously recorded ${ }^{12}$.

\section{De plus, selon Burger:}

The authority record ... documents decisions taken with respect to the form of access point, so that the laborious and demanding task of determining the current form of entry is done only once ${ }^{13}$.

Une fois produites, les notices d'autorité sont intégrées et conservées habituellement dans le fichier d'autorité d'une bibliothèque, c'est-à-dire dans un fichier autre que le catalogue bibliographique:

Authority records may be housed in the library catalog for public use, but are perhaps more commonly housed separately. If authority records are maintained in one separate file, this file is often referred to as the "official catalog"; if more than one file of authority records is kept, usually the records are grouped into files by type of access point ${ }^{14}$.

Toutefois, il faut établir des liens entre le fichier d'autorité et le fichier bibliographique d'une bibliothèque. En fait, ce n'est qu'à cette condition que ce dernier pourra être utile aux usagers.

To create an authority system, the authority file itself needs to be linked in some fashion to the bibliographic file... What makes the link implicit in printed catalogs is the presence of the identical form of name, title, or series on both the authority card and the catalog card... In machine catalogs, this linkage has also been affected in various ways... Ideally, there is a separate authority file with a machine link between an authority record and the bibliographic records that use that name as an access point ${ }^{15}$.

Par ailleurs, les bibliothécaires qui exécutent les tâches de contrôle d'autorité doivent constamment poursuivre les opérations de recherche et de revérification pour la mise à jour et l'évaluation de ce qui est déjà établi et acquis dans le fichier d'autorité. Aussi, étant donné que ce processus technique coûte cher. en temps et en argent, et qu'il n'est effectué qu'une seule fois, il est donc essentiel qu'il soit bien fait; sinon, c'est
8. Ibid., 128-129.

9. S. Michael Malinconico, «Bibliographic Data Base Organization and Authority File Control , Wilson Library Bulletin. vol. 54 (1979), 39.

10. Alors que les vedettes-matière sont déjà produites d'avance et disponibles dans des répertoires tels que Library of Congress Subject Headings (LCSH), Sears, our le Répertoire des vedettes-matière (RVM) de l'Université Laval, les autres formes standardisées de vedettes sont prescrites plutôt par les règles de catalogage en vigueur (par exemple, les RCAA2).

11. Alors que les renvois « voir » orientent l'usager des formes variantes de vedettes non-adoptées vers les formes établies de vedettes, adoptées dans le catalogue, les renvois «voir aussi» ont pour but de relier entre elles les formes établies de vedettes qui, par convention, sont reconnues comme étant connexes ou voisines.

12. Helen F. Schmierer, «The Relationship of Authority Control to the Library Catalog", Illinois Libraries, vol. 62 (1980), 602.

13. Robert H. Burger, Authority Work: the Creation, Use, Maintenance, and Evaluation of Authority Records, Littleton, Colorado, Libraries Unlimited, 1985, p. 5

14. Helen F Schmierer, "The Relationship...», 601.

15. Robert H. Burger, Authority Work..., p. 5-6. 
l'usager qui devra payer la note. Celui-ci, en effet, devra prendre plus de temps pour repérer les «bonnes" formes de vedettes, et trouver l'information qu'il cherche.

Signalons, enfin, que les bibliothécaires ou les catalogueurs doivent effectuer ce genre de travail d'une façon uniforme, en suivant des conventions communes, établies ou acceptées dans une seule bibliothèque, ou encore, dans plusieurs bibliothèques fonctionnant ensemble dans un réseau de catalogage:

Generally, those who pursue these activities in the context of a given library catalog perform these activities in a commonly agreed upon manner... the agreed upon, common conventions may be universal, or nearly so... (as for example, agreeing to follow the Anglo-American Cataloguing Rules) or local in character (as for example, an in-house manual of procedures). A clear understanding of the conventions to be followed is mandatory ${ }^{16}$.

\section{Les fonctions du catalogue}

Le contrôle d'autorité est donc un processus technique qui demande beaucoup de temps, d'efforts, et de jugement professionnel. En l'effectuant, on veut s'assurer que le catalogue (ou la base de données) d'une bibliothèque remplisse bien ses deux fonctions de base, telles que définies par Cutter dans ses Objects of the catalogue ${ }^{17}$ et reformulées dans les Paris Principles: la fonction de localisation et la fonction de regroupement. La première de ces fonctions peut être définie comme suit:

The first function helps a user learn what materials are in the library and where they are located. This is known as the finding function... This function satisfies the needs of those users searching for a simple, discrete item. It, however, can satisfy the needs of library users only part of the time ${ }^{18}$.

Quant à la deuxième fonction, Schmierer la définit dans les termes suivants:

The second function... enables the user to determine which particular items the library has by an author, which editions of a work, and which particular items on a given subject. The gathering function... brings together particular items sharing the same characteristic ${ }^{19}$.

La fonction de localisation requiert des points d'accès, au fichier d'une bibliothèque, mais ne rend pas essentielle la présence d'un vocabulaire contrôlé. Toutefois, la fonction de regroupement nécessite des vedettes dont la forme doit être standardisée, unique, et bien définie, donc vocabulaire contrôlé:

So that the user, for example, may identify a given person, or a given subject, and all of the items by a given person or all of the items on a given subject ${ }^{20}$.

La fonction de regroupement permet donc au fichier bibliographique d'une bibliothèque de répondre aux besoins des usagers, d'une façon plus efficace notamment en facilitant et en accélérant la recherche et le repérage de l'information. ${ }^{21}$ II n'est donc pas exagéré d'affirmer que le contrôle d'autorité est effectué essentiellement pour garantir cette fonction de collocation à l'intérieur d'un fichier bibliographique:

Bibliographic control... means the coverage and extent of access to informational materials available in libraries... To achieve control, a standardized system provided by cataloguing codes is needed to identify bibliographic items. It is in the latter aspect of bibliographic control that authority control is necessary to determine which bibliographic records can be attributable to an author or corporate body, which are parts of a series or which works are on a specific subject ${ }^{22}$.

\section{Implications sur les réseaux de catalogage}

Le contrôle d'autorité peut être effectué dans le fichier d'autorité d'une seule bibliothèque ou encore dans le fichier d'autorité (central) commun de plusieurs bibliothèques fonctionnant ensemble. En effet, de nos jours, étant donné les coupures bubgétaires imposées aux services d'information documentaire, on a tendance à assister, de plus en plus, à une coopération étroite entre bibliothèques, et à la création de réseaux de catalogage spécialisés où s'effectue notamment le contrôle d'autorité. La participation à un tel réseau comporte toutefois certaines obligations pour les bibliothèques qui en sont membres. Dans un premier temps, celles-ci sont tenues d'établir une entente pour atteindre les objectifs visés par ce dernier. Aussi, elles sont dans l'obligation d'accepter et de suivre des politiques et procédures communes, établies par convention, et qui impliquent le partage des ressources documentaires (notices bibliographiques et notices d'autorité), des moyens techniques de fonctionnement, des tâches de contribution et de maintenance, des coûts et des bénéfices, ainsi que le partage des tâches visant à réaliser le contrôle d'autorité. En outre, elles doivent accepter soit l'équilibre des forces en présence, soit la
16. Helen F Schmierer, «The Relationship...*, 600

17. Grace Bulaong, «Authorities and Standards... 41

18. Doris Hargrett Clack, «Authority Control...», 129.

19. Helen F. Schmierer, *The Relationship...»,600
20. Ibid.

21. Ibid, 602

22. Grace Bulaong, «Authorities and Standards... 41 
domination éventuelle de l'un des partenaires. Un réseau de catalogage peut être manuel ou automatisé, ce qui est de plus en plus courant actuellement. En effet, depuis l'adoption des RCAA2, la tendance est à l'automatisation et à l'accès en direct $^{23}$. De plus en plus de bibliothèques sont amenées à fermer ou à "geler» leurs fichiers manuels, et à procéder à l'automatisation et à la mise en commun des ressources documentaires disponibles dans ces mêmes fichiers. Tout ceci est fait, précisément, dans le but de participer à un réseau de catalogage automatisé qui implique la création et le maintien d'une base de données bibliographiques et d'un fichier d'autorité communs.

II faut insister également sur l'importance du contrôle d'autorité dans les fichiers ou bases de données des réseaux de catalogage. En effet, selon Bulaong:

In the manual card catalogue comprehensiveness or exhaustiveness of access is necessary because it is very time consuming... to try different forms to find all the materials with a particular attribute. This would be true even in a catalogue for one particular library, or even for several libraries with one cataloguing agency. But when a library is part of a network, the problem is compounded by having to reconcile forms used by other libraries... Once there is any dealing with other libraries in a network, some standardization or common agreement is needed even in a manual environnment ${ }^{24}$.

D'autre part, il ne faut pas sous-estimer l'importance du contrôle d'autorité dans les réseaux qui disposent de bases de données automatisées. En fait, il est vrai que certains auteurs et praticiens ne sont pas convaincus de l'utilité de ce dernier dans un tel environnement, et que d'autres encore ont tendance à le remettre en question 25,26 . Cependant, il n'en demeure pas moins selon Malinconico ${ }^{27}$, que le contrôle d'autorité est une opération nécessaire, et même essentielle, qui doit être effectuée dans de telles bases de données. D'ailleurs, ce point de vue est partagé par d'autres spécialistes dans le domaine, notamment par Culp ${ }^{28}$ et Bulaong:

...The efficiency of searching and location in an on-line environment is directly enhanced by authority control. As information databases have shown, it is possible to get around the lack of authority control by the use of keywords, truncated and combined search keys or qualified searches using Boolean operators. But what we are striving for is exhaustiveness. In searching information databases, nobody knows what is being missed because of lack of authority control. There is also no way of knowing when to stop the search 29 .

As we get more and more involved in automated bibliographic networks, authority control becomes more crucial rather than anachronistic ${ }^{30}$.

\section{Analyse coût-bénéfice}

Le contrôle d'autorité est donc un processus technique nécessaire qui doit être effectué dans les fichiers et bases de données des réseaux de catalogage. Toutefois, il comporte de sérieuses implications pour les réseaux et pour les bibliothèques qui en sont membres. Aussi faut-il, avant d'adhérer à de tels systèmes d'information, prendre en considération plusieurs facteurs importants. Tout d'abord, il est essentiel que l'on ait une bonne connaissance théorique et pratique du contrôle d'autorité:

Data in authority files do not remain static. They are dynamic and in a constant state of change. For a library to make adequate use of the national files, knowledge of the functions of authority control is mandatory. A thorough understanding of procedures and practices of authority work is also necessary. One must be aware of the area of potential problems and workable solutions ${ }^{31}$.

Les responsables de la bibliothèque doivent donc voir à ce que les membres du personnelbibliothécaires professionnels et techniciens qui travaillent dans le domaine du catalogage - reçoivent la formation et l'entraînement requis pour effectuer les tâches du contrôle d'autorité. Une analyse coût-bénéfice du système ou de la bibliothèque locale est souhaitable pour connaître les répercussions d'une éventuelle participation à un réseau. Une telle étude permet d'identifier les avantages et les inconvénients de l'automatisation (sile fichier est encore manuel), la standardisation ${ }^{32}$ (normalisation), la perte d'autonomie de la bibliothèque et toutes les modifications nécessaires ${ }^{33}$
23. Carol R. Krumm and Beverly I. McDonald, «Libraries on the Line», Technical Services Quarterly, vol. 1, no. 1 (19831984), 118.

24. Grace Bulaong, «Authorities and Standards..., 41

25. Helen F Schmierer, «The Relationship...», 602

26. Grace Bulaong, "Authorities and Standards... " 41

27. S. Michael Malinconico, «Bibliographic Data Base Organization..." 45

28. Gwen Miles Culp, «Authority Control within the Washington Library Network», in Authority Control: the Key to Tomorrow's Catalog, Oryx Press, 1982, p. 72.
29. Grace Bulaong, «Authorities and Standards...», 41.

30. Ibid., 43

31. Doris Hargrett Clack, «Authority Control...», 133.

32. Ibid., 134.

33. Par exemple, dans le fichier d'autorité local. 
qui devront être effectuées pour faciliter et assurer la participation de la bibliothèque au réseau. Elle permet également de prendre en considération d'autres facteurs tels les coûts et bénéfices:

The issue of relinquishing local needs for the sake of national standards will need to be carefully analyzed and all factors considered. Cost factors, convenience, and probable impact on service to users should be of primary importance 34 .

La question des coûts et des bénéfices est effectivement très importante. Par exemple, on doit considérer les coûts qu'occasionneront la formation et l'entraînement du personnel, ainsi que l'achat du matériel et des moyens techniques de fonctionnement (terminaux d'ordinateur, etc.). II faut tenir compte du fait que le contrôle d'autorité est un processus technique dispendieux puisqu'il demande beaucoup de temps, d'efforts et de jugement professionnel:

Rigourous authority control is expensive; however, no control is even more so. Included in the costs of authority control are the time spent in searching, personnel costs, the expense of acquiring and maintaining equipment, the cost of equipment and supplies, typing, proofing, and filing. Costs are also accrued for making changes and resolving conflicts ${ }^{35}$.

II faut considérer également les coûts de la recherche effectuée par l'usager, qu'elle soit réussie ou non, ainsi que les bénéfices que l'on peut tirer du contrôle d'autorité:

There is a cost for a successful search by a user and for a failed one. Failure has significant financial implications for a library. An automated system will improve the integrity of the files and will speed up the operations, but, there is no evidence that the actual dollar figures will be reduced. The greatest potential savings to be accrued probably will be in reduced duplication and redundancy 36

Par ailleurs, avant de prendre la décision d'adhérer à un réseau de catalogage, les responsables de la bibliothèque doivent se demander jusqu'à quel point celle-ci peut se permettre de perdre son autonomie. En fait, la participation à un tel réseau l'obligera-t-elle à s'y intégrer totalement, et à négliger les besoins locaux (vedettes locales, etc.)? Ou encore, lui permettra-t-elle de développer son propre fichier d'autorité local, parallèlement au fichier central du réseau? Coexistence ou fusion? Voilà des questions importantes auxquelles il faudra songer avant de s'engager dans un tel projet, surtout lorsque l'on sait que dans plusieurs réseaux de catalogage, on a tendance à encourager la création et l'utilisation d'une seule base de données et d'un seul fichier d'autorité communs.

C'est le cas de la base SHARAF ${ }^{37}$, par exemple, qui s'est donné comme objectif de réduire au minimum la prolifération des bases de données et des fichiers d'autorité locaux ainsi que les coûts élevés que cette situation entraîne. Dans d'autres réseaux, il semble toutefois, selon $\mathrm{Clack}^{38}$, que l'on permette aux bibliothèques membres de développer leurs propres fichiers d'autorité locaux. Ceux-ci peuvent coexister en marge du système central tout en fonctionnant de pair avec lui.

Enfin, dans d'autres réseaux comme le Washington Library Network (WLN), il n'y a qu'un seul fichier d'autorité central auquel tous les membres ont accès. Toutefois, son système automatisé en direct permet aux bibliothèques participantes de conserver dans ce même fichier central leurs notices d'autorité locales et d'en avoir l'accès exclusif 39 .

En somme, la participation à un réseau de catalogage peut se faire à des degrés divers: collaboration occasionnelle (accès réciproque aux services); collaboration régulière (où une bibliothèque maintient et utilise un fichier d'autorité local); et intégration complète des unités participantes dans un système d'information unique, possédant un seul fichier d'autorité central (où les fichiers d'autorité locaux sont inexistants). Cependant, quels que soient les modalités et le type de participation choisis, il est certain que les bibliothèques qui songent à devenir membre d'un tel réseau devront apporter des modifications à leurs propres fichiers d'autorité pour qu'ils soient compatibles et puissent se fusionner, ou coexister, avec le fichier d'autorité central du réseau:

Participation in a network is impossible if a library chooses not to change its name authority file to fit the system of the network. A library may choose to give up its local authority file in order to participate in a network. It may be necessary, however, to change a great many entries initially in order for the files to be merged. Also, the library will lose control over decisions regarding any future modifications to the system 40 .

Les bibliothèques devront aussi s'entendre dès le départ afin de résoudre les problèmes que peuvent poser la gestion du ou des fichiers d'autorité. L'on devra déterminer qui sera chargé de cette responsabilité et qui pourra contribuer au fichier d'autorité central. En effet, selon Clack:

Some libraries that are part of a network or system are developing their own individual automated authority control system... The ques-
34. Doris Hargrett Clack, «Authority Control...», 134

35. Ibid., 138

36. Ibid., 138-139

37. Grace Bulaong, «Authorities and Standards. $\infty, 41$.
38. Doris Hagrett Clack, "Authority Control...», 136.

39. Gwen Miles Culp, «Authority Control within the Washington Library...», p. 64

40. Doris Hargrett Clack, «Authority Control...», 135. 
tions with the broadest implications that have been raised concern the maintenance of the systems authority files once the local authority system is up and running. Should they coexist? Or should they merge? If they are merged, who should maintain, administer, control, or even contribute to the file? Funding and location of the experts will decide the answers to many of the question raised ${ }^{4}$.

Les bibliothèques doivent donc considérer plusieurs facteurs avant de prendre la décision d'adhérer à un réseau de catalogage:

Advantages and disadvantages will vary from library to library, depending on how closely the library adheres to the latest cataloguing rules, how many local variations the local system requires, and how willing the library is to give up its autonomy ${ }^{42}$.

Quelle que soit cette décision, toutefois, il faut comprendre que la participation à un réseau de catalogage permet également aux bibliothèques de réduire, de façon appréciable, les dépenses en ressources documentaires et autres, en temps et en argent, et d'éviter la duplication et la redondance des notices d'autorité et des notices bibliographiques qu'impliquerait le développement indépendant des fichiers respectifs de ces bibliothèques. C'est ce qui se produit, notamment, dans SHARAF:

If an authority work is shared, as in SHARAF, with participants accessing a union authority file on-line, whatever is found as an authority record could be used by a participating library. Related to cost is the reduction of authority record creation and elimination of individual file maintenance. For those libraries that maintain authority record, relying on an on-line database will eliminate keeping files in libraries of participating libraries in a cooperative effort such as SHARAF ${ }^{43}$

Quant aux tâches d'entretien (corrections, ajouts, mises à jour), elles sont facilitées et allégées puisqu'elles sont, soit effectuées par un des membres du réseau ${ }^{44}$, soit partagées ou distribuées ${ }^{45}$ entre les bibliothèques participantes:

The other important feature is automatic updating... Any heading can be changed according to current cataloguing codes and terminology, by keying the change one time only, regardless of number of bibliographic records with that heading... When a heading in the authority record is changed, the bibliographic records with that heading automatically reflect this change ${ }^{46}$.

Par ailleurs, les bibliothèques membres d'un réseau de catalogage doivent s'entendre entre

41. Ibid, 136

42. Ibid, 135

43. Grace Bulaong, "Authorities and Standards...", 43.

44. Doris Hargrett Clack, "Authority Control...», 136 elles et suivre les mêmes normes ou règles (RCAA2, ISBD, etc.), accepter les mêmes répertoires ou outils de travail (LCSH, RVM, ouvrages de référence, etc.), et adopter des procédures communes en vue d'effectuer de façon uniforme les tâches du catalogage et du contrôle d'autorité. Afin de bien s'intégrer au réseau, les nouveaux membres doivent, dans un premier temps, voir à l'adoption systématique des RCAA2, du moins dans le contexte nord-américain. Ces mêmes bibliothèques sont tenues également, d'une part, de procéder à la fermeture de leurs fichiers manuels, et d'autre part, à prendre les mesures nécessaires pour faire la transition vers l'automatisation et en arriver à la production de notices bibliographiques et de notices d'autorité en format MARC, et d'autres produits et services qui seront disponibles aux membres du réseau : par exemple, un catalogue collectif, un catalogue COM, des microfiches, etc.

Chaque bibliothèque participante du réseau doit également voir à ce que le personnel de son service de catalogage effectue les tâches du contrôle d'autorité en suivant les étapes prescrites par convention. Ce genre de travail est fait dans le but de modifier le fichier d'autorité local, donc d'apporter les modifications nécessaires aux notices d'autorité de ce dernier pour qu'elles soient compatibles et puissent être versées et mises en commun dans le fichier d'autorité central. Ajoutées aux autres notices qui seront produites ultérieurement, elles pourront alors contribuer à mettre en valeur les notices bibliographiques de format MARC saisies dans la base de données et partagées par les membres du réseau.

Les ressources documentaires, les coûts et les tâches ainsi partagés entre les bibliothèques participantes du réseau, la période de transition vers l'automatisation et vers l'intégration (fusion ou coexistence) au système d'information se fera plus facilement pour les unités membres. L'adoption des RCAA2 coûtera moins cher et se fera plus rapidement et plus facilement que si elle avait été faite individuellement par chaque unité participante.

On pourra également économiser au niveau des tâches de maintenance, qu'elles soient distribuées ou centralisées, puisque les coûts en seront partagés. Quant au catalogage à la source, celui-ci sera fait en suivant les normes établies par convention (RCAA2, LCSH, LC Name Authorities, etc.), et les notices seront saisies dans le format MARC. Toutefois, des vérifications devront être faites dans la base de données avant que l'on crée de nouvelles notices bibliographiques. En effet, comme l'affirme Bulaong:

45. Gwen Miles Culp, «Authority Control within the Washington Library...», p. 66.

46. Grace Bulaong, «Authorities and Standards...», 43. 
Experience even in automated cataloguing has generally shown that it is still cheaper to adopt a record than to catalogue originally ${ }^{47}$.

En prenant de telles précautions, on évitera la duplication et la redondance des notices, ainsi que les dépenses inutiles en temps et en argent. II faudra également insister et veiller à la qualité des notices du fichier d'autorité, ainsi qu'à la qualité des notices bibliographiques contenues dans la base de données.

Finalement, une fois l'intégration au réseau de catalogage complétée et une fois surmontés les problèmes de transition, les bibliothèques membres pourront poursuivre ensemble une coopération étroite et avantageuse visant toujours les mêmes objectifs: I'allégement et le partage des tâches, la multiplication des ressources documentaires et le partage des coûts. Elles sauront que, dorénavant, les périodes de restrictions budgétaires seront peut-être moins pénibles et moins durement ressenties.

\section{Conclusion}

Nous croyons que le contrôle d'autorité est nécessaire et même essentiel parce qu'il permet d'en arriver éventuellement au partage des ressources documentaires et au contrôle bibliographique aux niveaux régional, national et même international. Des ententes entre pays au niveau de la normalisation, ainsi que l'automatisation croissante des fichiers bibliographiques de bibliothèques, nous permettront peut-être d'en arriver à de tels progrès sur une plus grande échelle que ce que l'on a connu jusqu'ici.

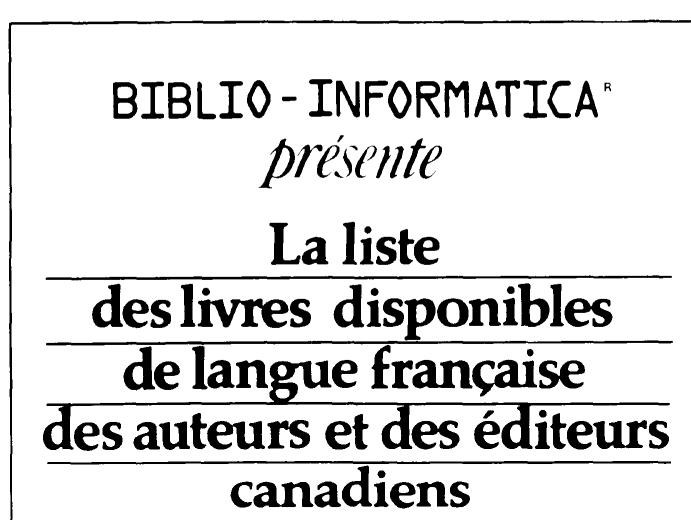

\author{
Canadian
}

Authors \& Publishers

French Books in Print
Un outil de commercialisation et de référence unique!
Plus de

20,000 titres 439 éditeurs 260 distributeurs

Enfin ò votre disposition, une banque de données originale, pratique et facile à consulter présentant toute la production canadienne de langue trançaise.

\section{en 3 volumes Auteurs · Titres • Sujets}

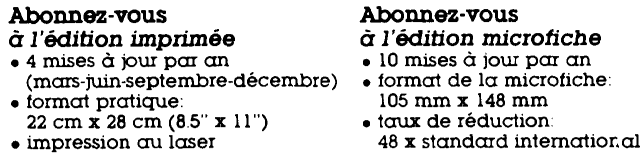

Renseignement et abonnements:

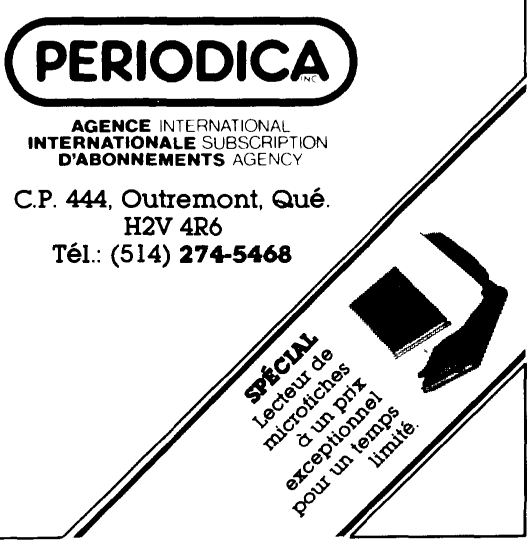

